\title{
METODE SUTRISNO (MASTRIS) SUATU INOVASI DALAM PENJUMLAHAN ANGKA BANYAK
}

\author{
Mohammad Sutrisno Hardiono \\ STAI Yapata Al-Jawami Cileunyi Bandung \\ Komplek Pesantren Al-Jawawi No 87 Cileunyi Bandung \\ s.hardiono@yahoo.co.id
}

\begin{abstract}
Banyak ditemukan berbagai metode operasi dasar aritmetika seperti metode Trachtenberg, metode horizoltal/ metris, jarimatika, matemagica, dan mental aritmetika sempoa. Metode-metode tersebut dimaksudkan untuk mempercepat hitungan yang disebut sebagai aritmetika cepat. Kemampuan berhitung cepat dapat dibagi ke dalam tiga kategori besar, yaitu ofensif (menghitung cepat), defensive (ada system koreksi jawaban), dan menghibur. Metode Trachtenberg (MT) merupakan jenis ofensif dan defensive karena bertujuan untuk menghitung secara cepat dan dapat mengkoreksi kesalahan. Sedangkan metode konvensional (MK) menghitung dengan kecepatan biasa dan tidak terdapat sistem koreksi. MT kalah cepat dengan metode konvensional (MK) yang menggunakan kaidah 10 (k10). Namun MT mempunyai keunggulan di bidang pengkoreksian jawaban dan dapat menjumlahkan dari kolom mana saja secara acak. Dengan mengubah mindset menjadi k-10 seperti sistem MK, metode Sutrisno (MasTris) menyederhanakan prosedur k11 pada MT sehingga dari sisi waktu metode ini lebih cepat dalam perhitungan dibandingkan dengan MT dan MK.
\end{abstract}

Keywords: Metode, Trachtenberg, Konvensional, MasTris.

\section{PENDAHULUAN}

Manusia telah menggunakan operasi dasar aritmetika sejak zaman prasejarah atau zaman sebelum ditemukannya tulisan. Hal ini terbukti dari adanya goresan garis tegak lurus di Tulang Ishango sekitar tahun 20.000 - 180.000 SM. Aritmetika terus mengalami perkembangan setelah manusia mengenal tulisan. Semula penghitungan cabang ilmu itu dilakukan dengan simbol atau gambar, misalnya garis. Ketika manusia mengenal tulisan penghitungannya pun mulai memakai angka. Penghitungan dasar artimetika dengan angka mengalami perkembangan di zaman Helenistik. Yakni zaman dalam sejarah Yunani Kuno yang berlangsung di era tahun 323 - 146 SM. Meski demikian, penghitungan aritmetika pada masa itu masih dipengaruhi oleh mitos.

Operasi dasar aritmetika berkembang lagi setelah ditemukannya bilangan nol (0). Brahmagupta (masa hidup 598 - 668) dianggap sebagai orang yang memperkenalkan operasi dasar aritmetika bilangan 0 . Ia adalah seorang ilmuwan matematika dan ahli astronomi asal India. Pada abad ke-7, Brahmagupta menetapkan rumusan hasil perkalian, pembagian, penjumlahan dan pengurangan bilangan 0 dan bilangan lain. Misalnya, semua bilangan yang bila dijumlahkan dengan 0 hasilnya adalah bilangan itu sendiri. Penemuan Brahmagupta ini sangat penting bagi cabang ilmu aritmetika. Karenanya, banyak yang menjulukinya sebagai Bapak Aritmetika (http://www.berani.co.id, diakses tanggal 15 Januari 2015).

Namun di dunia Barat, Ilmu Matematika termasuk aritmetika lebih banyak dipengaruhi oleh karya alKhawarizmi dibanding karya para penulis pada Abad ke-7. Nama asli al-Khawarizmi adalah Abu Abdullah Muhammad Ibnu Musa. Dia dikenal dengan sebutan al-Khawarizmi karena berasal dari Khawarizm Baghdad Irak, sebuah daerah di timur laut Kaspia.

Karya Aljabarnya yang paling monumental berjudul al-Mukhtasar fi Hisab al-Jabr wal-Muqabalah (Ringkasan Perhitungan Aljabar dan Perbandingan). Dalam buku itu diuraikan pengertianpengertian geometris. Ia juga menyumbangkan teorema segitiga sama kaki yang tepat, perhitungan tinggi serta luas 
segitiga, dan luas jajaran genjang serta lingkaran. Dengan demikian, dalam beberapa hal al-Khawarizmi telah membuat aljabar menjadi ilmu eksak (http://www.azzein.com, diakses tanggal 15 Januari 2015).

Dalam bukunya, al-Khawarizmi memperkenalkan kepada dunia ilmu pengetahuan angka 0 (nol) yang dalam bahasa Arab disebut sifr. Sebelum al-Khawarizmi memperkenalkan angka nol, para ilmuwan mempergunakan abakus, semacam daftar yang menunjukkan satuan, puluhan, ratusan, ribuan, dan seterusnya, untuk menjaga agar setiap angka tidak saling tertukar dari tempat yang telah ditentukan dalam hitungan. Akan tetapi, hitungan seperti itu tidak mendapat sambutan dari kalangan ilmuwan Barat ketika itu, dan mereka lebih tertarik untuk mempergunakan raqam al-binji (daftar angka Arab, termasuk angka nol), hasil penemuan al-Khawarizmi.

Al-Khawarizmi adalah penemu aljabar yang merupakan generalisasi dari wilayah aritmetika maka beliau adalah tokoh penting dari aritmetika. Aljabar, sebagai sebuah ilmu berbicara mengenai sifat operasi dari bilangan riil, mendefiniskan struktur cincin matematika, matematika bisang, mempelajari karakter khusus vektor dan masih banyak lagi lainnya. Aljabar merupakan bidang ilmu yang sangat berguna. Hampir semua siswa pernah mempelajarinya di sekolah (http://tokoh-penemu-aljabar-al-

khawarizmi.html, diakses tanggal 29 Maret 2015).

Dewasa ini banyak ditemukan berbagai metode operasi dasar aritmetika seperti metode Trachtenberg, metode horizoltal/ metris, jarimatika, matemagica, dan mental aritmetika sempoa. Metode-metode tersebut dimaksudkan untuk mempercepat hitungan yang disebut sebagai aritmetika cepat. Aritmetika cepat adalah suatu kemampuan untuk menghitung operasi-operasi aritmetika seperti penjumlahan (tambah-kurang), perkalian, dan pembagian dengan cepat tanpa bantuan kalkulator bahkan untuk bilanganbilangan yang nilainya cukup besar (http://wikipedia.com, ensiklopedia bebas, diakses tanggal 29 maret 2015).

Kemampuan berhitung cepat dapat dibagi ke dalam tiga kategori besar, yaitu ofensif (menghitung cepat), defensive (ada system koreksi jawaban), dan menghibur (http://wikipedia.com, ensiklopedia bebas, diakses tanggal 29 maret 2015). Metode Trachtenberg merupakan jenis ofensif dan defensive karena bertujuan untuk menghitung secara cepat dan dapat mengkoreksi kesalahan. Sedangkan metode konvensional menghitung dengan kecepatan biasa dan tidak terdapat sistem koreksi.

Metode Trachtenberg (MT) ditemukan oleh Jakow Trachtenberg pada tahun 1944. Beliau adalah pendiri Institut Matematika di Zurich, Swiss (Soeparmo, 1990). Metode cepat matematika dasar Trachtenberg ini sering juga disebut "stenografi matematika". Metode ini hanya memerlukan kemampuan menghitung dari satu sampai sebelas, meniadakan pembagian panjang seperti yang kita kenal, dan menghilangkan daftar perkalian.

Berdasarkan sejumlah "kunci" yang sederhana, metode ini mudah dikuasai dan membawa serta keuntungan berupa kecepatan lebih besar, kemudahan dalam menangani bilangan, dan ketepatan yang makin meningkat. Perhitungan matematika dapat diselesaikan dalam waktu kurang dari $30 \%$ dari biasanya. Dan dengan sistem pengecekan cepat ini menjamin 99\% dalam ketepatannya. Dalam kegunaannya, sistem kilat matematika dasar ini dapat membuat setiap orang dewasa bisa menjadi kalkulator yang sangat terampil, cepat, dan tepat (Soeparmo, 1992).

Pada operasi penjumlahan (tambahkurang), Trachtenberg mengenalkan kaidah 11 ( $k$ 11), cek sisa sembilan (CSS), dan cek jawaban Trachtenberg (CT). metode penjumlahan ala Trachtenberg sangat terasa kegunaannya apabila angka yang dijumlahkan atau dikurangkan itu berderet panjang dan banyak. Misalkan $347654426+$ $768865+9087767555-90+\ldots$. Meskipun orang menggunakan alat bantu hitung (kalkulator atau software hitung), itu tidak serta merta dapat mengkoreksi jawaban. Pada kondisi seperti itu apalagi dimana alat bantu hitung tidak dipunyai/ ditemukan maka MT adalah alternative solusi yang baik agar dapat menjumlahkan dengan tepat dan sekaligus mengetahui jawabannya benar. Sebenarnya MT dalam operasi penjumlahan tidak termasuk katagori hitung cepat. MT kalah cepat dengan metode konvensional (MK). Namun MT mempunyai keunggulan di bidang pengkoreksian jawaban dan dapat menjumlahkan dari kolom mana saja secara acak. 
Adapun kendala lainnya dalam penjumlahan, MT mengitung dengan $\mathrm{k} 11$ tidak seperti sistem konvensional yaitu kaidak 10 ( k10). Ini menyebabkan pengguna operasi ini harus merubah mainset-nya dari $\mathrm{k} 10$ ke k 11 . Penyesuaian ini membutuhkan waktu yang relative lama. Kendala inilah yang akan diperbaikan dengan metode Sutrisno (MasTris). Selain menangani kendala tersebut, MasTris menyederhanakan prosedur penjumlahan dan mengganti CT dengan cek Sutrisno (CS)..

\section{KAJIAN PUSTAKA}

Ada tiga kajian yang dipaparkan di bagian ini, yaitu metode konvensional, metode Trachtenberg, dan metode Sutrisno. Adapaun penjelasannya dibahas satu persatu berikut ini.

\section{a. Metode Konvensional (MK)}

Semua orang yang sudah mengenyam pendidikan dasar tentunya sudah memahami dan mahir dalam penjumlahan konvensional. Dimulai dari hafalan sambil memainkan jemarinya, anak-anak melafalkan angka 1 sampai 10 dan seterusnya. Kemudian dengan bantuan benda semacam lidi, anak-anak mulai menjumlah dan menguranginya. Sambil belajar menulis angka, akhirnya mereka hafal, paham, dan terampil pada proses penjumlahan.

Penjumlahan pada MK dapat diproses secara horizontal maupun vertikal. Pada proses vertikal, penjumlahan pada MK harus dimulai dari kanan. Kemudian dilanjutkan ke kolom yang lebih kiri sampai selesai. Kaidah yang digunakan adalah kaidah sepuluh (k 10). Kaidah 10 adalah dimana hasil penjumlahan mencapai angka 10 maka ditulis 0 dan sisa 1 . Sisa 1 tersebut nantinya untuk ditambahkan pada kolom yang lebih kiri-nya.

\section{b. Metode Trachtenberg (MT)}

Metode Trachtenberg dalam penjumlahan menggunakan kaidah 11 (k 11), prosedur Trachtenberg, dan sistem pengkoreksian jawaban (Soeparmo, 1992). Kaidah 11 (k11) yaitu setiap hasil jumlah mencapai 11 itu dianggap 0 dan sisa 1 . Jika hasil jumlah adalah 12 maka diberi nilai 1 dan sisa 1 . Namun hasil jumlah adalah 10 maka dituliskan 10 saja. Hal ini dikarenakan basik angkanya adalah antara 0 sampai dengan 11 .
Prosedur pada MT agak berbeda dengan MK. Setiap ada sisaan maka ditulis pada angka tersebut dengan tanda 1 pada kolom yang sama. Pada angka-angka yang dijumlahkan terdapat dua proses jawaban sementara yaitu jumlah jalan (JJ) dan jumlah tanda (JT). Angka pada JJ dan JT dijumlahkan dengan langkah kuda dalam permainan catur,berpola huruf "L". Penyelesain akhir pada penjumlahan Trachtenberg (PT) memiliki keunikan tersendiri namun melalui prosedur yang relative panjang. Adapun kaidah penjumlahannya berbasis k 10. Pengkoreksian jawaban penjumlahan pada MT didasarkan pada ketercocokan antara cek sisa sembilan (CSS) dan cek Trachtenberg (CT). Apabila hasil system CSS dan CT mempunyai angka yang sama maka pengerjaan penjumlahan pada MT adalah benar. Jika ada satu atau lebih angka yang tidak sama maka diartikan bahwa pada kolom tersebut penjumlahannya tidak benar dan dihitung ulang. Penghitung ulangan tersebut dilakukan pada kolom tersebut. Ada tiga unsur yang dijumlahkan yaitu JJ, JT, dan JT. Hasil penjumlahan tersebut menjadi CT. Pada CT dikenal system tambah ringkas atau kaidah ringkas $(\mathrm{kr})$.

\section{c. Metode Sutrisno (MasTris)}

Berbasis prinsip penjumlahan pada MK dan MT diperolehlah sebuah system penjumlahan MasTris. Prinsip tersebut di antaranya adalah kaidah 10, Jumlah jalan (JJ), Jumlah tanda (JT), Panah lurus (pion jalan), Panah miring (pion makan), Hasil $(\mathrm{H})$, Cek sisa Sembilan (CSS), Kaidah 9 (k 9), Kaidah ringkas (kr), dan Cek Sutrisno (CS).

Tanda panah lurus kebawah dioperasikan untuk hasil (H). Prosedurnya adalah $\mathrm{JJ}+\mathrm{JT}=\mathrm{H}$. Hasil penjumlahan tersebut dicek menggunakan CS. Cara mencari CS menggunakan tanda panah miring. Sebagaimana yang sudah dijelaskan di bagian CSS di atas, jika proses CS nilainya sama dengan CSS maka prosedur dan hasil penjumlahan MasTris sudah benar.

\section{METODOLOGI}

\section{a. Populasi dan Sampel}

Populasi dalam penelitian ini adalah seluruh siswa MA Al-Jawami Cileunyi Bandung. Sampel yang diteliti diambil secara acak sederhana sebanyak 24 siswa yang kemudian dibagi ke dalam 3 kelompok. Pembagian tersebut bertujuan untuk membagi penggunaan metode yang 
digunakan. 8 siswa menggunakan metode konvensional (MK), 8 orang menggunakan metode Trachtenberg (MT) dan 8 orang menggunakan metode Sutrisno (MT).

b. Desain Penelitian

Desain penelitian yang diambil adalah kuantitatif. Begitu juga dengan desain risetnya berjenis kuantitatif. Adapun metode penelitiannya, penulis mengambil penelitian ekstensi atau penelitian pengembangan.

c. Alur Pengolahan Data

Adapun data yang diambil dari 24 sampel adalah

1. Nilai dari tes $0-100$ (skala data rasio) disebut $\mathrm{X}_{1}$,

2. Waktu pengerjaan 0-180 (skala data rasio) disebut $\mathrm{X}_{2}$, dan

3. Metode penjumlahan MK (kode 1), MT (kode 2), dan MasTris (kode 3).

Data tersebut dikumpulkan melalui tes esai dengan 3 soal. Soal pertama penjumlahan 4 baris, kedua ada 8 baris, dan terakhir 10 baris. Pada satu barisnya terdapat 5 angka. Banyaknya angka ini dimaksudkan untuk keadilan penskoran nilai tes.

Data dianalisis menggunakan Manova satu jalur. Dimana pada Manova akan diketahui perbedaan ketiga metode dan pengaruhnya terhadap nilai tes maupun waktu pengerjaan.

\section{HASIL DAN PEMBAHASAN}

Data pada penelitian ini adalah

\begin{tabular}{|c|c|c|c|}
\hline Obs & Metode & Nilai & Waktu \\
\hline 1 & MK & 18 & 180 \\
\hline 2 & MK & 36 & 100 \\
\hline 3 & MK & 0 & 60 \\
\hline 4 & MK & 54 & 180 \\
\hline 5 & MK & 54 & 170 \\
\hline 6 & MK & 18 & 100 \\
\hline 7 & MK & 18 & 180 \\
\hline 8 & MK & 100 & 170 \\
\hline 9 & MT & 100 & 180 \\
\hline 10 & MT & 18 & 180 \\
\hline 11 & MT & 36 & 170 \\
\hline 12 & MT & 64 & 180 \\
\hline 13 & MT & 0 & 180 \\
\hline
\end{tabular}

\begin{tabular}{|c|c|c|c|}
\hline Obs & Metode & Nilai & Waktu \\
\hline 14 & MT & 18 & 180 \\
\hline 15 & MT & 18 & 165 \\
\hline 16 & MT & 0 & 176 \\
\hline 17 & MasTris & 54 & 100 \\
\hline 18 & MasTris & 54 & 120 \\
\hline 19 & MasTris & 64 & 120 \\
\hline 20 & MasTris & 100 & 140 \\
\hline 21 & MasTris & 100 & 160 \\
\hline 22 & MasTris & 18 & 180 \\
\hline 23 & MasTris & 100 & 90 \\
\hline 24 & MasTris & 54 & 80 \\
\hline
\end{tabular}

Tabel 1 Deskriptif Statistik

\begin{tabular}{|ll|r|r|r|}
\hline & Metode & Mean & $\begin{array}{c}\text { Std. } \\
\text { Deviation }\end{array}$ & $\mathrm{N}$ \\
\hline Nilai & MasTris & 68.0000 & 29.70329 & 8 \\
& MK & 37.2500 & 31.62165 & 8 \\
& MT & 31.7500 & 34.43317 & 8 \\
& Total & 45.6667 & 34.62930 & 24 \\
\hline Wkt & MasTris & 123.7500 & 34.61523 & 8 \\
& MK & 142.5000 & 48.03273 & 8 \\
& MT & 176.3750 & 5.80486 & 8 \\
& Total & 147.5417 & 39.64843 & 24 \\
\hline
\end{tabular}

Berdasarkan Tabel 1, nilai tes memiliki nilai rataan yang tinggi pada metode Sutrisno. Kemudian disusul oleh metode Tractenberg dan metode konvensional. Kemudian waktu pengerjaan, metode yang paling cepat adalah metode Sutrisno. Sedangkan metode konvensional menempati urutan kedua dan terakhir metode Tractenberg.

Selanjutnya analisis ditujukan pada kesignifikansian pengaruh dari variabel independen (metode) pada semua variabel dependen (nilai dan tes). Pada Tabel 2 pada bagian Metode, empat uji multivariate mempunyai nilai p-value menunjukkan $<0,05$ maka signifikan pada level kepercayaan $95 \%$. Oleh karena itu maka sedikitnya ada satu pengaruh yang signifikan dari variabel independen pada semua variabel dependen.

Setelah diketahui paling tidak ada satu variable dependen yang terpengaruh dari variable independen maka uji pots hoc melanjutkan yang mana akan digunakan apakah Uji Benferroni atau uji Games-Howell. Uji ini nantinya digunakan untuk memperinci satu persatu pengaruh metode terhadap nilai maupun waktu. 
Tabel 2 Multivariate Testsd

\begin{tabular}{|l|l|r|r|r|r|r|r|r|}
\hline \multicolumn{2}{|c|}{ Effect } & Value & $\mathrm{F}$ & $\begin{array}{c}\text { Hypothesis } \\
\mathrm{df}\end{array}$ & $\begin{array}{c}\text { Error } \\
\mathrm{df}\end{array}$ & Sig. & $\begin{array}{c}\text { Noncent. } \\
\text { Parameter }\end{array}$ & $\begin{array}{c}\text { Observed } \\
\text { Powerb }\end{array}$ \\
\hline Intercept & $\begin{array}{l}\text { Pillai's } \\
\text { Trace }\end{array}$ & .956 & 215.268 & 2.000 & 20.000 & .000 & 430.535 & 1.000 \\
\cline { 2 - 9 } & $\begin{array}{l}\text { Wilks' } \\
\text { Lambda }\end{array}$ & .044 & 215.268 & 2.000 & 20.000 & .000 & 430.535 & 1.000 \\
\cline { 2 - 9 } & $\begin{array}{l}\text { Hotelling's } \\
\text { Trace }\end{array}$ & 21.527 & 215.268 & 2.000 & 20.000 & .000 & 430.535 & 1.000 \\
\cline { 2 - 8 } & $\begin{array}{l}\text { Roy's } \\
\text { Largest } \\
\text { Root }\end{array}$ & 21.527 & 215.268 & 2.000 & 20.000 & .000 & 430.535 & 1.000 \\
\hline Metode & $\begin{array}{l}\text { Pillai's } \\
\text { Trace }\end{array}$ & .501 & 3.511 & 4.000 & 42.000 & .015 & 14.042 & .822 \\
\hline $\begin{array}{l}\text { Wilks' } \\
\text { Lambda }\end{array}$ & .518 & 3.896 & 4.000 & 40.000 & .009 & 15.585 & .862 \\
\hline $\begin{array}{l}\text { Hotelling's } \\
\text { Trace }\end{array}$ & .894 & 4.248 & 4.000 & 38.000 & .006 & 16.994 & .891 \\
\hline $\begin{array}{l}\text { Roy's } \\
\text { Largest } \\
\text { Root }\end{array}$ & .851 & 8.939 & 2.000 & 21.000 & .002 & 17.878 & .950 \\
\hline
\end{tabular}

Pada Tabel 3 menunjukkan hasil uji homogenitas yaitu uji Levene. Dikatakan semua variabel memiliki varian yang sama apabila nilai sig. $>0,05$. Nilai ini nantinya akan mempengaruhi pilihan uji Post Hoc apa yang digunakan. Apabila Sig. $>0,05$ maka uji Post Hoc menggunakan Uji Benferroni, sedangkan jika $<0,05 \quad$ maka menggunakan Games-Howell. Hasil diatas menunjukkan variabel nilai tidak memiliki varian yang sama sebab Sig. $<0,05$ sehingga uji Post Hoc yang digunakan nantinya adalah Games-Howell. Adapun variable waktu memakai uji Benferroni.

Tabel 3 Levene's Test of Equality of Error Variances ${ }^{a}$

\begin{tabular}{|l|r|r|r|r|}
\hline & \multicolumn{1}{|c|}{ F } & df1 & df2 & Sig. \\
\hline Nilai & .039 & 2 & 21 & .962 \\
Waktu & 12.739 & 2 & 21 & .000 \\
\hline
\end{tabular}

Tests the null hypothesis that the error variance of the dependent variable is equal across groups.

a. Design: Intercept + Metode
Pada Tabel 4 menunjukkan nilai uji Manova. Pada uji F, disuguhkan dengan beberapa nilai: Corrected Model, Intercept, Metode, Error dan Total. Perhatian ditujukkan pada baris "Metode". Pada baris tersebut ada 2 baris lagi, yaitu "Nilai" dan "Waktu". Maksud dari hal tersebut adalah tiap baris menunjukkan hasil uji pengaruh satu variabel independen yaitu metode terhadap masing-masing variabel dependen. Dari hasil di atas, pada nilai kolom "Sig." dinyatakan signifikan apabila nilai Sig. < 0,05. Pada Tabel diatas hanya nilai tes saja yang signifikan. Artinya adalah

a. Metode secara bermakna mempengaruhi waktu pengerjaan tes dengan P-value 0,019.

b. Metode secara bermakna tidak mempengaruhi nilai tes dengan $\mathrm{P}$ Value 0,072 . berikut. 
Tabel 4 Tests of Between-Subjects Effects

\begin{tabular}{|c|c|c|c|c|c|c|c|c|}
\hline Source & $\begin{array}{l}\text { Dependent } \\
\text { Variable }\end{array}$ & $\begin{array}{l}\text { Type III } \\
\text { Sum of } \\
\text { Squares }\end{array}$ & $\mathrm{df}$ & $\begin{array}{l}\text { Mean } \\
\text { Square }\end{array}$ & $\mathrm{F}$ & Sig. & $\begin{array}{l}\text { Noncent. } \\
\text { Parameter }\end{array}$ & $\begin{array}{l}\text { Observed } \\
\text { Powerb }\end{array}$ \\
\hline \multirow{2}{*}{$\begin{array}{l}\text { Corrected } \\
\text { Model }\end{array}$} & Nilai & 6106.333 & 2 & 3053.167 & 2.986 & .072 & 5.971 & .518 \\
\hline & Waktu & 11382.583 & 2 & 5691.292 & 4.824 & .019 & 9.649 & .737 \\
\hline \multirow{2}{*}{ Intercept } & Nilai & 50050.667 & 1 & 50050.667 & 48.944 & .000 & 48.944 & 1.000 \\
\hline & Waktu & 522445.042 & 1 & 522445.042 & 442.868 & .000 & 442.868 & 1.000 \\
\hline \multirow{2}{*}{ Metode } & Nilai & 6106.333 & 2 & 3053.167 & 2.986 & .072 & 5.971 & .518 \\
\hline & Waktu & 11382.583 & 2 & 5691.292 & 4.824 & .019 & 9.649 & .737 \\
\hline \multirow{2}{*}{ Error } & Nilai & 21475.000 & 21 & 1022.619 & & & & \\
\hline & Waktu & 24773.375 & 21 & 1179.685 & & & & \\
\hline \multirow{2}{*}{ Total } & Nilai & 77632.000 & 24 & & & & & \\
\hline & Waktu & 558601.000 & 24 & & & & & \\
\hline \multirow{2}{*}{$\begin{array}{l}\text { Corrected } \\
\text { Total }\end{array}$} & Nilai & 27581.333 & 23 & & & & & \\
\hline & Waktu & 36155.958 & 23 & & & & & \\
\hline
\end{tabular}

yaitu metode apabila memiliki Sig. < 0,05.

Pada Tabel 5 menunjukkan hasil Uji Post Hoc. Karena nilai uji homogenitas menunjukkan Sig. $>0,05$ pada variable waktu variabel, maka pengaruh variabel independen terhadap variabel waktu menggunakan uji Benferroni. Namun pada nilai tes menggunakan Games-Howell.

Dikatakan ada perbedaan/ sama variabel dependen berdasarkan variabel independen
Berdasarkan tabel diatas dapat dikatakan sebagai berikut:

a. Perbedaan waktu berdasarkan metode, yang memiliki perbedaan adalah Metode Sutrisno dan Metode Trachtenberg.

b. Perbedaan nilai tes berdasarkan metode, tidak ada perbedaan dari ketiga metode.

\begin{tabular}{|c|c|c|c|c|c|c|c|c|}
\hline \multicolumn{9}{|c|}{ Tabel 5 Multiple Comparisons } \\
\hline \multirow{2}{*}{\multicolumn{2}{|c|}{ Dependent Variable }} & \multirow[t]{2}{*}{ (I) Metode } & \multirow[t]{2}{*}{ (J) Metode } & \multirow{2}{*}{$\begin{array}{c}\text { Mean } \\
\text { Difference } \\
\text { (I-J) }\end{array}$} & \multirow[b]{2}{*}{$\begin{array}{l}\text { Std. } \\
\text { Error }\end{array}$} & \multirow[b]{2}{*}{ Sig. } & \multicolumn{2}{|c|}{$\begin{array}{c}\text { 95\% Confidence } \\
\text { Interval } \\
\end{array}$} \\
\hline & & & & & & & $\begin{array}{l}\text { Lower } \\
\text { Bound }\end{array}$ & $\begin{array}{l}\text { Upper } \\
\text { Bound } \\
\end{array}$ \\
\hline \multirow[t]{8}{*}{ Nilai } & \multirow[t]{6}{*}{ Bonferroni } & \multirow[t]{2}{*}{ MasTris } & MK & 30.7500 & 15.98921 & .204 & 10.8435 & 72.3435 \\
\hline & & & MT & 36.2500 & 15.98921 & .102 & -5.3435 & 77.8435 \\
\hline & & \multirow[t]{2}{*}{ MK } & MasTris & -30.7500 & 15.98921 & .204 & 72.3435 & 10.8435 \\
\hline & & & MT & 5.5000 & 15.98921 & 1.000 & 36.0935 & 47.0935 \\
\hline & & \multirow[t]{2}{*}{ MT } & MasTris & -36.2500 & 15.98921 & .102 & 77.8435 & 5.3435 \\
\hline & & & MK & -5.5000 & 15.98921 & 1.000 & $\begin{array}{r}- \\
47.0935\end{array}$ & 36.0935 \\
\hline & \multirow{2}{*}{$\begin{array}{l}\text { Games- } \\
\text { Howell }\end{array}$} & \multirow[t]{2}{*}{ MasTris } & MK & 30.7500 & 15.33873 & .148 & -9.4137 & 70.9137 \\
\hline & & & MT & 36.2500 & 16.07766 & .097 & -5.9334 & 78.4334 \\
\hline
\end{tabular}




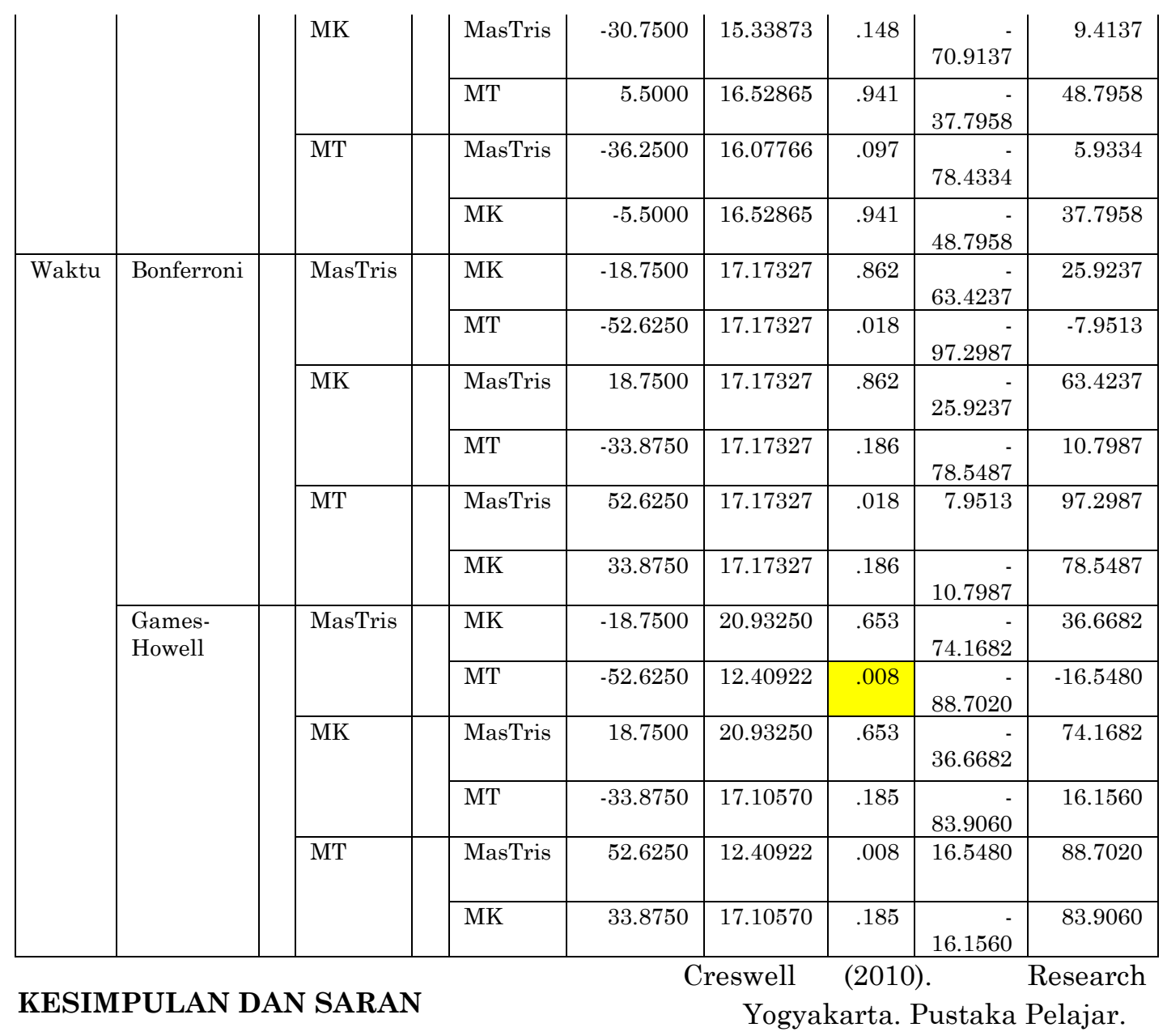

Design.

a. Kesimpulan

Metode secara bermaka hanya mempengaruhi waktu pengerjaan tes. Berdasarkan waktu pengerjaan, metode Sutrisno berbeda secara signifikan dengan metode Tractenberg. Jika dilihat pada rataan waktu pengerjaan maka waktu yang tersingkat adalah MasTris. Metode secara bermakna tidak mempengaruhi nilai tes.

b. Saran

Penelitian yang dilakukan masih terdapat keterbatasan sehingga perlu dibahas pemahaman yang lebih mendalam untuk kajian penelitian berikutnya. Oleh karenanya peneliti menyarankan untuk dilakukan kajian mengenai objek penelitian yang diperluas sehingga dapat melihat metode mana yang unggul secara luas dan kajian pengembangan metode MasTris pada perkalian, pembagian, dan operasi lainnya.

\section{DAFTAR PUSTAKA}

Borg and Gall (1983:772). Educational Research, An Introduction. New York and London. Longman Inc.
Gay, L.R. (1991). Educational Evaluation and Measurement: Com-petencies for Analysis and Application.Second edition. New York: Macmillan Publishing Compan.

http://www.azzein, diakses tanggal 15 Januari 2015

http://www.berani.co.id, diakses tanggal 15 Januari 2015.

http://www.etih.staff.ipb.ac.id/files/2011/07/eti ka-penelitian.pdf, diakses tanggal 8 Maret 2015.

http://www.maa.org/features/112404howdoido. html. diakses tanggal 29 Maret 2015.

http://www.wikipedia, diakses tanggal 15 Januari 2015.

http://tokoh-penemu-aljabar-al-

khawarizmi.html, diakses tanggal 29 Maret 2015. 
Rita C. Richey, J. D. K., Wayne A. Nelson. (2009). Developmental Research : Studies of Instructional Design and Development.

Seels, Barbara B. \& Richey, Rita C. (1994). Teknologi Pembelajaran: Definisi dan Kawasannya. Penerjemah Dewi S. Prawiradilaga dkk. Jakarta: Kerjasama IPTPI LPTK UNJ.

Soeparmo. 1990. Sistem Kilat Matematika Dasar Metode Trachtenberg. Bandung. Rosda Jayaputra.

Soeparmo. 1992. Sistem Kilat Matematika Dasar Metode Trachtenberg. Bandung. Rosda Jayaputra.

Sugiyono. (2011). Metode Penelitian Kuantitatif, Kualitatif, dan R \& D. Bandung: Alfabeta.

Plomp, Tj. (1994). Educational Design: Introduction. From Tjeerd Plomp (eds). Educational \&Training System Design: Introduction. Design of Education and Training (in Dutch).Utrecht (the Netherlands): Lemma. Netherland. Faculty of Educational Science andTechnology, University of Twente

Tessmer, Martin. (1998). Planning and Conducting Formative Evaluations. Philadelphia: Kogan Page.

van den Akker J. (1999). Principles and Methods of Development Research. Pada J. van den Akker, R.Branch, K. Gustafson, Nieven, dan T. Plomp (eds), Design Approaches and Tools in Education and Training (pp. 1-14). Dortrech: Kluwer Academic Publishers.

van den Akker J., dkk. (2006). Educational Design Research. London and New York: Routledge. 